\section{RSP}

http://www.rsp.fsp.usp.br/
Revista de Saúde Pública

\title{
Workforce in the pharmaceutical services of the primary health care of SUS, Brazil
}

\author{
Marselle Nobre Carvalho', Juliana Álvares", Karen Sarmento Costa"II,IV, , Augusto Afonso Guerra Junior", \\ Francisco de Assis Acurcio", Ediná Alves Costa" , Ione Aquemi Guibu" ${ }^{\mathrm{VII}}$, Orlando Mario Soeiro ${ }^{\mathrm{VIII}}$, \\ Margô Gomes de Oliveira Karnikowski ${ }^{1 \mathrm{x}}$, Silvana Nair Leite ${ }^{\mathrm{x}}$ \\ I Departamento de Saúde Coletiva. Universidade Estadual de Londrina. Londrina, PR, Brasil \\ " Departamento de Farmácia Social. Faculdade de Farmácia. Universidade Federal de Minas Gerais. \\ Belo Horizonte, MG, Brasil \\ III Núcleo de Estudos de Políticas Públicas. Universidade Estadual de Campinas. Campinas, SP, Brasil \\ Iv Programa de Pós-Graduação em Saúde Coletiva. Departamento de Saúde Coletiva. Faculdade de Ciências Médicas. \\ Universidade Estadual de Campinas. Campinas, SP, Brasil \\ $\checkmark$ Programa de Pós-Graduação em Epidemiologia. Faculdade de Medicina. Universidade Federal do Rio Grande do Sul. \\ Porto Alegre, RS, Brasil \\ vı Instituto de Saúde Coletiva. Universidade Federal da Bahia. Salvador, BA, Brasil \\ VII Faculdade de Ciências Médicas. Santa Casa de São Paulo. São Paulo, SP, Brasil \\ VIII Faculdade de Ciências Farmacêuticas. Pontifícia Universidade Católica de Campinas. Campinas, SP, Brasil \\ ıx Faculdade de Ceilândia. Universidade de Brasília. Brasília, DF, Brasil \\ x Departamento de Ciências Farmacêuticas. Universidade Federal de Santa Catarina. Florianópolis, SC, Brasil
}

Correspondence:

Silvana Nair Leite

Departamento de Ciências

Farmacêuticas

Universidade Federal de Santa

Catarina - Campus Trindade

88.040-900

Florianópolis, SC, Brasil

E-mail: silvana.nair.leite@ufsc.br

Received: Apr 20, 2016

Approved: Nov 30, 2016

How to cite: Carvalho MN,

Álvares J, Costa KS, Guerra Junior AA, Acurcio FA, Costa EA, et al. Workforce in the pharmaceutical services of the primary health care of SUS, Brazil. Rev de Saude Publica. 2017;51 Suppl 2:16s

Copyright: This is an open-access article distributed under the terms of the Creative Commons Attribution License, which permits unrestricted use, distribution, and reproduction in any medium, provided that the original author and source are credited.

\section{ABSTRACT}

OBJECTIVE: To characterize the workforce in the pharmaceutical services in the primary care of the Brazilian Unified Health System (SUS).

METHODS: This is a cross-sectional and quantitative study, with data from the Pesquisa Nacional sobre Acesso, Utilização e Promoção do Uso Racional de Medicamentos - Serviços, 2015 (PNAUM - National Survey on Access, Use and Promotion of Rational Use of Medicines - Services, 2015). For the analysis, we considered the data stratification into geographical regions. We analyzed the data on workers in the municipal pharmaceutical services management and in the medicine dispensing units, according to the country's regions. For the statistical association analysis, we carried out a Pearson correlation test for the categorical variables.

RESULTS: We analyzed 1,175 pharmacies/dispensing units, 507 phone interviews (495 pharmaceutical services coordinators), and 1,139 professionals responsible for medicine delivery. The workforce in pharmaceutical services was mostly constituted by women, aged from 18 to 39 years, with higher education ( $90.7 \%$ in coordination and $45.5 \%$ in dispensing units), having permanent employment bonds (public tender), being for more than one year in the position or duty, and with weekly work hours above $30 \mathrm{~h}$, working both in municipal management and in medicine dispensing units. We observed regional differences in the workforce composition in dispensing units, with higher percentage of pharmacists in the Southeast and Midwest regions.

CONCLUSIONS: The professionalization of municipal management posts in primary health care is an achievement in the organization of the workforce in pharmaceutical services. However, significant deficiencies exist in the workforce composition in medicine dispensing units, which may compromise the medicine use quality and its results in population health.

DESCRIPTORS: Pharmaceutical Services, manpower. Patient Care Team. Workers. Primary Health Care. Health Services Research. Unified Health System. 


\section{INTRODUCTION}

Since its implementation in the late 1980s, the Brazilian Unified Health System (SUS) expanded the number of work posts in all health care levels, especially in primary health care (PHC). The expansion and diversification of health workforce occurred with an increase in the number of doctors and nurses and the inclusion of new professional categories, such as physical therapists, pharmacists, nutritionists, speech and language therapists, physical education professionals, among others ${ }^{6}$.

SUS holds more than $60 \%$ of the health sector facilities, assists about $80 \%$ of the population, and absorbs about $80 \%$ of the sector's workforce, which represents almost two millions jobs in the country. It is estimated that $52 \%$ of nurses, $44 \%$ of doctors, $27 \%$ of dentists, $11 \%$ of pharmacists, and $10 \%$ of psychologists are civil servants ${ }^{13}$.

With the objective of reorganizing SUS and meeting the principles of integrality, equity, and universality of health care, and having PHC as an organizer of the health services network, the Brazilian Ministry of Health implemented the Programa Saúde da Familia (PSF - Brazilian Family Health Program) in 1994, oriented to the reduction of maternal and infant mortality, especially in the North and Northeast of the country. In 2006, the government published the Política Nacional de Atenção Básica (PNAB - National Primary Health Care Policy), which transformed the PSF into the Estratégia Saúde da Familia (ESF Brazilian Family Health Strategy), reaffirming its major role in the reorganization of $\mathrm{PHC}^{14}$.

Differing form the Family Health teams, comprised by doctors, nurses, dental surgeons, oral health assistants or technicians, nursing assistants or technicians, and community health agents, the Núcleos de Apoio à Saúde da Família (NASF - Family Health Support Centers) teams, implemented more recently, can be constituted by numerous professional categories, among which the pharmacists are ${ }^{6,15}$.

Around the world, as well as in Brazil, the publishing of the World Health Report 2006 highlighted the discussion on the health work in all sectors, including pharmacy, by pointing out the shortage of workers in the health sector and the unequal workforce distribution?

Most Brazilian studies on health workforce refer to the nursing category in its diverse work scenarios ${ }^{10}$. Compared to other higher education professional categories, there is still few studies, among which is the one by Carvalho et al. ${ }^{6}$ on the expansion and diversification of the workforce in SUS's Primary Health Care. In this study, the authors point out NASF as an important strategy for the insertion of other professional categories into PHC, especially physical therapists, psychologists, social assistants, nutritionists, and pharmacists.

During the implementation and organization of SUS, changes in funding and access to essential materials also occurred, notably the National Drug Policy, in 1998. The Politica Nacional de Assistência Farmacêutica (PNAF - National Policy of Pharmaceutical Services), published by the Resolution no. 338 of the National Health Council, in 2004, reaffirmed the pharmaceutical services as an integral part of the health system, the specific funding block creation oriented towards guaranteeing the policy's execution in the country, and the need for human resources development for pharmaceutical services recognition ${ }^{4}$.

In 1998, the report from the consultative council of the WHO is a milestone for the reorientation of the pharmacist actions on health systems, shifting the actions focus from the medicines to the user. Thus, the pharmacist was recognized as the best-qualified professional to conduct actions for improving the access and promoting the rational use of medicines, being essential to organize the necessary services to the complete development of pharmaceutical services ${ }^{1}$.

In Brazil, studies show that, despite of the pharmaceutical category growth as a workforce in PHC, in a $75 \%$ ratio from 2008 to $2013^{6}$, technician professionals and other professional categories act on the public and private medicine dispensing services ${ }^{5,18}$. 
In this context, to know the pharmaceutical services' workforce in primary health care in indispensable to the assessment of achievements and challenges in availability management, access, and medicines' use in the country. This would allow the preparing and following of public policies, meeting the professionals' real educational and qualification needs for the development of pharmaceutical services and for the achievement of better health outcomes with pharmaceutical services.

The Pesquisa Nacional sobre Acesso, Utilização e Promoção do Uso Racional de Medicamentos Serviços, 2015(PNAUM - National Survey on Access, Use and Promotion of Rational Use of Medicines - Services, 2015) aimed to characterize the organization of pharmaceutical services in SUS primary health care - for promoting the access and rational use of medicines -, as well as to identify and discuss the issues that interfere in the municipal pharmaceutical services consolidation.

This study is part of PNAUM - Services and aimed to characterize the pharmaceutical services workforce in the Brazilian primary health care networks.

\section{METHODS}

PNAUM is a cross-sectional, exploratory, and evaluative study, composed of an information gathering in a representative sample of primary health care services, in cities of Brazilian regions. Several study populations were considered in the sampling plan, with samples stratified by regions, which constitute the study domains ${ }^{2}$. The Brazilian Ministry of Health's Decree no. 2,077, of September 17, 2012, instituted the survey.

The sampling considered the cities' regional representation: capitals; bigger cities, selecting the $0.5 \%$ biggest cities in the region; and smaller cities, totaling 120 cities by region. In each city, primary health care services were sampled according to the total number of services in that city. For this study, we analyzed the face-to-face interviews made with the professionals responsible for the medicines' delivery in the SUS primary health care services, in addition to the observations of the pharmaceutical services facilities of all sampled services and phone interviews with those responsible for municipal pharmaceutical services (one in each city). The interview scripts comprised the pharmaceutical services organization in each city and health service, including professional practice, available structures, and work processes. The observation script for the health services facilities comprised a checklist and photographical register that were applied by trained professionals. The research team collectively built, pretested, and validated all survey instruments in health services in the state of Minas Gerais. The interviewers received specific training for each applied instrument. The complete survey methodology description is available at Álvares et al. ${ }^{2}$

The data were collected from July to December 2014. For the analysis, we considered the data stratification by geographical regions.

All data were analyzed with the assistance of the SPSS software, version 22, extracting the frequencies of the study variables. All analyses considered sample weights and the analysis plan structure for complex samples. For the statistical association analysis, the Pearson correlation test was carried out for categorical variables. The significance level adopted was $p<0.05$. The results showed representativeness for the Brazilian geographical regions.

The participants signed the informed consent form. PNAUM - Services was approved by the National Research Ethics Committee of the National Health Council, by Opinion no. $398,131 / 2013$.

\section{RESULTS}

We analyzed 1,175 pharmacies/dispensing units, 507 phone interviews (495 pharmaceutical services coordinators), and 1,139 professionals responsible for medicines delivery. 
The workforce in the municipal pharmaceutical services management was mostly composed of women. The Northeast was the only region where men occupy $50.1 \%$ (95\%CI 39.2-61.0) of the coordination posts (Table 1).

Concerning education level, most cities had managers with higher education degree. The Northeast region stands out by two important aspects: $22.2 \%$ (95\%CI 14.4-32.8) of the cities had managers with specialization (lato sensu) and 3.8\% (95\%CI 1.2-11.4) had managers with master's or doctor's degree (stricto sensu) in any knowledge area. All regions showed predominance of pharmacists (> 80.0\%) as coordinators of municipal pharmaceutical services (Table 1).

Concerning the type of employment bond, in the Southeast and South regions, cities with permanent managers predominated, whereas in other regions there was a certain similarity between permanent and commission-based workers. All regions showed prevalence of time in position higher than 12 months (> 70.0\%). Excluding the Northeast, the managers of the other regions had weekly work hours higher than 30h (Table 1).

Pharmacists predominated in the composition of the management of municipal pharmaceutical services in all regions. More than $90.0 \%$ of the Brazilian cities had pharmacists in the coordination of pharmaceutical services (Figure 1).

Women were the majority of workers in the medicine dispensing units of primary health care health services in all regions, notably in the Northeast and South, where women predominated in more than $80.0 \%$ of the cities (Table 2).

Concerning the workers' age group, North and Southeast showed similar patterns: the groups from 18 to 39 years and from 40 to 59 years were virtually equivalent, i.e., the workforce was almost equally distributed in these age groups (Table 2).

In the Midwest, Southeast, and South, more than $60.0 \%$ of the cities had permanent workers, whereas in the North and Northeast, the percentage of public permanent and contracted workers was proportional. The Southeast, presented a significant percentage of cities with outsourced workers in the medicine dispensing units

Table 1. Characterization of municipal pharmaceutical services managers, Brazil and regions. National Survey on Access, Use and Promotion of Rational Use of Medicines - Services, 2015. $(n=507)$

\begin{tabular}{|c|c|c|c|c|c|c|}
\hline \multirow{2}{*}{ Variable } & North & Northeast & Midwest & Southeast & South & Brazil \\
\hline & $\%(95 \% \mathrm{Cl})$ & $\%(95 \% \mathrm{Cl})$ & $\%(95 \% \mathrm{Cl})$ & $\%(95 \% \mathrm{Cl})$ & $\%(95 \% \mathrm{Cl})$ & $\%(95 \% \mathrm{Cl})$ \\
\hline \multicolumn{7}{|l|}{ Sex } \\
\hline Female & $64.4(54.0-73.6)$ & $49.9(39.9-60.8)$ & $67.3(57.3-75.9)$ & $63.2(53.1-72.3)$ & $73.2(63.7-81.0)$ & $62.0(56.9-66.9)$ \\
\hline Male & $36.6(26.4-46.0)$ & $50.1(39.2-61.0)$ & $32.7(24.1-42.7)$ & $36.8(27.7-46.9)$ & $26.8(19.0-36.3)$ & $38.0(33.1-43.1)$ \\
\hline \multicolumn{7}{|l|}{ Age group (years) } \\
\hline 18 to 39 & $75.1(64.8-83.2)$ & $66.3(55.1-75.9)$ & $84.0(75.2-90.1)$ & $69.6(59.5-78.1)$ & $72.5(62.9-80.4)$ & $70.9(65.8-75.5)$ \\
\hline 40 to 59 & $24.9(16.8-35.2)$ & $29.9(20.7-40.9)$ & $16.0(9.9-24.8)$ & $30.3(21.9-40.4)$ & $27.5(19.6-37.1)$ & $27.9(23.4-33.0)$ \\
\hline$\geq 60$ & - & $3.8(1.2-11.4)$ & - & $1.0(0-5.0)$ & - & $1.2(0.4-3.5)$ \\
\hline \multicolumn{7}{|l|}{ Employment bond } \\
\hline Permanent & $37.5(28.2-47.9)$ & $39.9(29.7-51.1)$ & $45.5(35.8-55.5)$ & $63.2(53.1-72.3)$ & $76.8(67.6-84.0)$ & $56.0(51.0-60.9)$ \\
\hline Commission-based & $35.6(26.4-46.0)$ & $34.6(25.0-45.7)$ & $25.5(17.7-35.1)$ & $14.8(9.0-23.4)$ & $10.0(5.5-17.6)$ & $22.0(18.1-26.5)$ \\
\hline Other & $26.9(18.7-37.0)$ & $25.5(17.0-36.2)$ & $29.1(20.9-39.0)$ & $22.0(14.8-31.5)$ & $13.2(7.9-21.3)$ & $22.0(18.0-26.6)$ \\
\hline \multicolumn{7}{|c|}{ Workweek (weekly hours) } \\
\hline$\leq 30$ & $45.3(35.3-55.7)$ & $62.4(51.3-72.4)$ & $22.9(15.5-32.4)$ & $27.9(20.0-37.4)$ & $27.9(20.0-37.4)$ & $39.1(34.4-44.0)$ \\
\hline$>30$ & $54.7(44.3-64.7)$ & $37.6(27.6-48.7)$ & $77.1(67.6-84.5)$ & $71.8(61.9-79.9)$ & $72.1(62.6-80.0)$ & $60.9(56.0-65.6)$ \\
\hline \multicolumn{7}{|c|}{ Time in position (months) } \\
\hline$\leq 12$ & $38.4(28.8-49.0)$ & $28.6(19.6-39.4)$ & $39.4(30.1-49.5)$ & $24.4(16.8-34.1)$ & $23.3(16.0-32.5)$ & $37.7(23.3-32.5)$ \\
\hline$>12$ & $61.6(51.0-71.2)$ & $71.4(60.4-80.4)$ & $60.6(50.5-69.9)$ & $75.6(65.9-83.2)$ & $76.7(67.5-84.0)$ & $72.3(67.5-76.7)$ \\
\hline
\end{tabular}

Source: PNAUM - Services, 2015. Permanent: public tender or transferred servant. $p$-values $($ sex $)=0.008 ; p$ (age group) $=0.022 ; p$ (employment bond) $<0.001$; $\mathrm{p}$ (weekly workhours $)<0.001 ; \mathrm{p}$ (time in position $)=0.167$. 
(7.6\%; 95\%CI 3.5-15.6). Regarding the experience period and weekly work hours, all regions showed prevalence of more than one year in medicine dispensing and $30 \mathrm{~h}$ weekly work hours (Table 2).

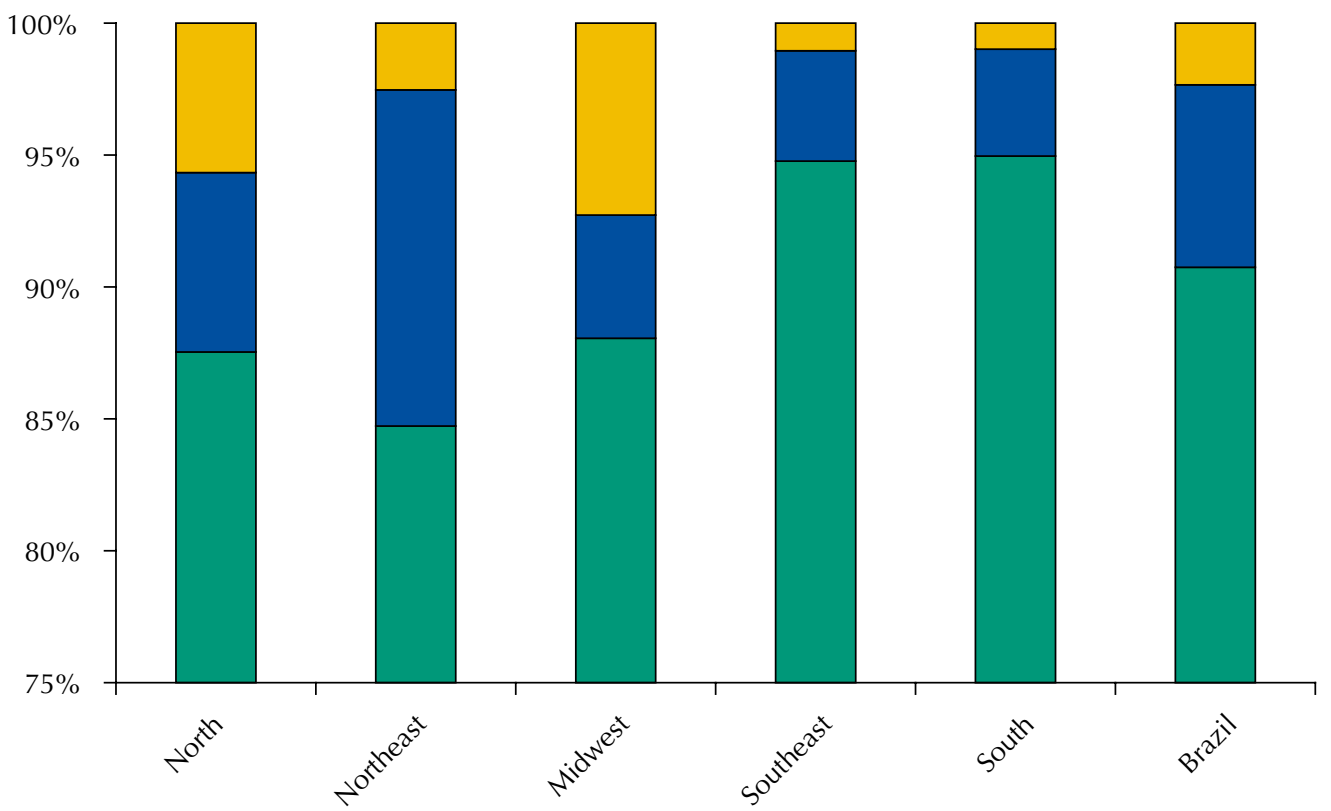

Higher education (pharmacist) $\square$ Higher education (other) $\square$ High school or incomplete higher education Source: PNAUM - Services, 2015. p-value $=0.023$.

Figure 1. Education level and profession of the pharmaceutical services managers in the primary health care, Brazil and regions. National Survey on Access, Use and Promotion of Rational Use of Medicines - Services, 2014. $(n=507)$.

Table 2. Characterization of workers in the medicine dispensing units in SUS primary health care, Brazil and regions. National Survey on Access, Use and Promotion of Rational Use of Medicines - Services, 2015. ( $n=1,139)$

\begin{tabular}{|c|c|c|c|c|c|c|}
\hline \multirow{2}{*}{ Variable } & North & Northeast & Midwest & Southeast & South & Brazil \\
\hline & $\%(95 \% \mathrm{Cl})$ & $\%(95 \% \mathrm{Cl})$ & $\%(95 \% \mathrm{Cl})$ & $\%(95 \% \mathrm{Cl})$ & $\%(95 \% \mathrm{Cl})$ & $\%(95 \% \mathrm{Cl})$ \\
\hline \multicolumn{7}{|l|}{ Sex } \\
\hline Female & $77.5(70.6-83.2)$ & $80.9(72.2-87.3)$ & $68.8(51.6-82.0)$ & $69.7(52.8-82.6)$ & $87.4(81.1-91.9)$ & $77.4(71.2-82.6)$ \\
\hline Male & $22.5(16.8-29.4)$ & $19.1(12.7-27.8)$ & $31.2(18.0-48.4)$ & $30.3(17.4-47.2)$ & $12.6(8.1-18.9)$ & $22.6(17.4-28.8)$ \\
\hline \multicolumn{7}{|l|}{ Age group (years) } \\
\hline 18 to 39 & $59.3(52.9-65.4)$ & $68.6(57.0-78.3)$ & $71.1(59.6-80.4)$ & $51.0(37.9-63.9)$ & $66.0(50.4-78.7)$ & $61.9(55.0-68.3)$ \\
\hline 40 to 59 & $38.4(32.3-44.9)$ & $29.1(20.4-39.6)$ & $25.5(17.1-36.2)$ & 45.9 (33.9-58.4) & $32.5(19.9-48.2)$ & $35.6(29.6-42.1)$ \\
\hline$\geq 60$ & $2.3(1.2-4.3)$ & $2.3(0.8-6.2)$ & $3.4(0.7-15.8)$ & $3.1(1.6-5.9)$ & $1.5(0.3-7.2)$ & $2.5(1.5-4.0)$ \\
\hline \multicolumn{7}{|l|}{ Employment bond } \\
\hline Permanent & $43.1(33.9-52.7)$ & $42.7(30.7-55.7)$ & $61.8(45.0-76.2)$ & $66.2(49.4-79.7)$ & $76.2(56.2-88.8)$ & $57.0(49.3-64.4)$ \\
\hline Contract & $53.4(43.3-63.2)$ & $48.5(36.4-60.8)$ & $33.0(19.7-49.8)$ & $15.9(9.8-24.7)$ & $12.2(6.3-22.4)$ & $31.5(25.7-37.9)$ \\
\hline Outsource & $0.5(0.1-3.5)$ & $3.0(1.2-7.4)$ & $2.8(0.6-11.8)$ & $7.6(3.5-15.6)$ & $1.4(0.5-4.0)$ & $4.0(2.3-6.7)$ \\
\hline Commission-based & $0.9(0.2-3.7)$ & $4.0(1.4-10.5)$ & $1.5(0.4-5.5)$ & $9.5(2.0-34.6)$ & $9.5(2.2-31.9)$ & $6.2(2.6-14.0)$ \\
\hline Other & $2.1(1.1-4.1)$ & $1.8(0.6-4.9)$ & $0.9(0.2-3.9)$ & $0.8(0.2-3.2)$ & $0.9(0.2-3.1)$ & $1.3(0.7-2.4)$ \\
\hline \multicolumn{7}{|c|}{ Workweek (weekly hours) } \\
\hline$\leq 30$ & $43.8(31.2-57.2)$ & $32.5(20.2-47.8)$ & $29.5(16.2-47.6)$ & $39.1(24.7-55.5)$ & $34.8(18.9-55.0)$ & $35.8(28.1-44.3)$ \\
\hline$>30$ & $56.2(42.8-68.8)$ & $67.5(52.2-79.8)$ & $70.5(52.4-83.8)$ & $60.9(44.5-75.3)$ & $65.2(45.0-81.1)$ & $64.2(55.7-71.9)$ \\
\hline \multicolumn{7}{|c|}{ Experience period (months) } \\
\hline$\leq 12$ & $10.6(6.0-18.0)$ & $11.0(6.5-18.1)$ & $8.1(2.6-22.5)$ & $8.8(3.8-18.8)$ & $12.7(6.2-24.0)$ & $10.4(7.4-14.4)$ \\
\hline$>12$ & $89.4(82.0-94.0)$ & $89.0(81.9-93.5)$ & $91.9(77.5-97.4)$ & $91.2(81.2-96.2)$ & $87.3(76.0-93.8)$ & $89.6(85.6-92.6)$ \\
\hline
\end{tabular}

Source: PNAUM - Services, 2015. Assistant: pharmacy or nursing assistant. Permanent: public tender or transferred servant. $p$-values (sex) $=0.087$;

$\mathrm{p}($ age group $)=0.139 ; \mathrm{p}($ employment bond $)=0.001 ; \mathrm{p}($ weekly work hours $)=0.803 ; \mathrm{p}($ experience period $)=0.886$. 


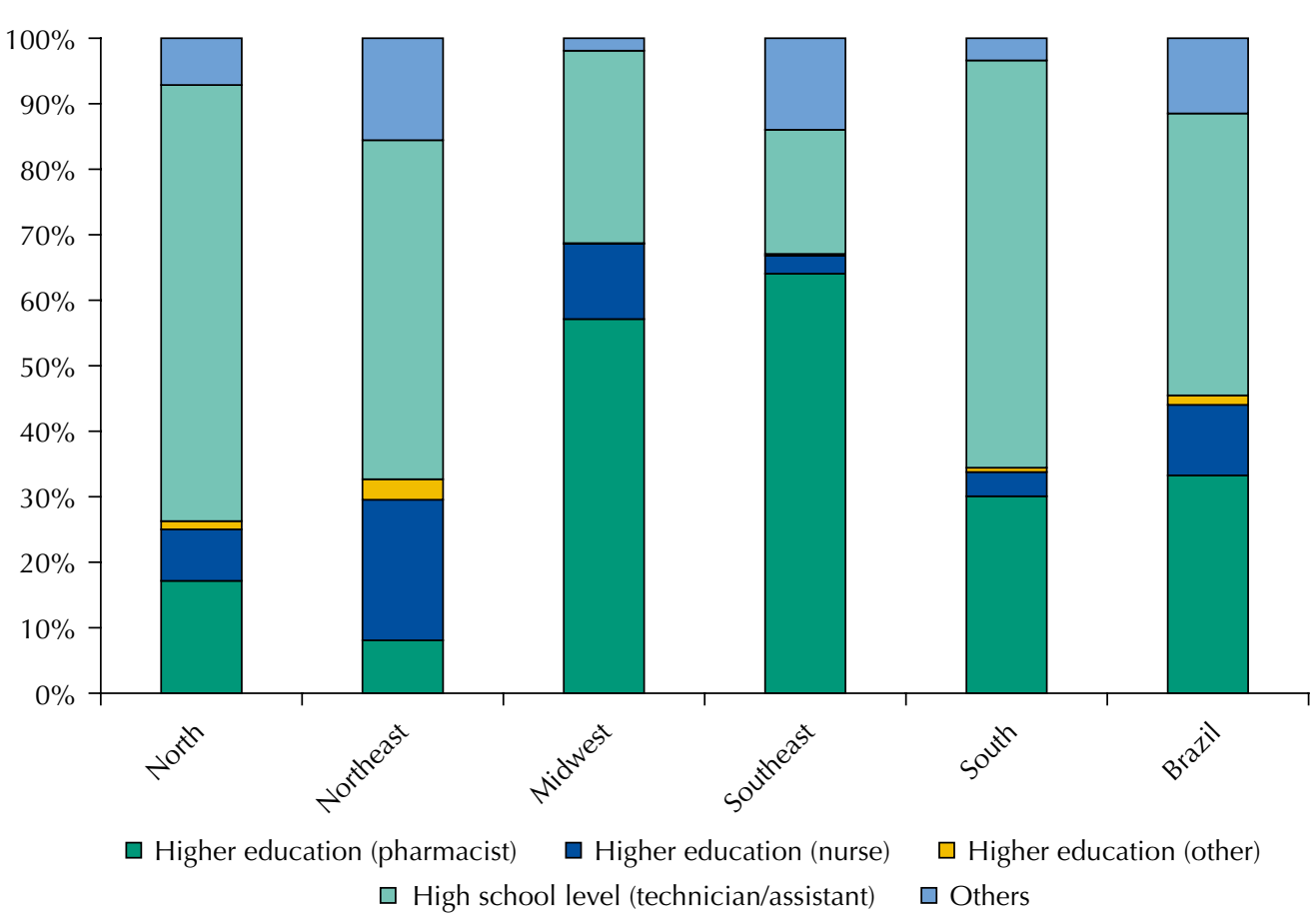

Source: PNAUM - Services, 2015. p-values < 0.001 .

Figure 2. Education level and profession of workers in the dispensing units of the primary health care, Brazil and regions. National Survey on Access, Use and Promotion of Rational Use of Medicines Services, 2015. $(n=1,139)$.

While the coordination was mostly constituted by women with higher education, especially graduated in Pharmacy, the medicine delivery to users was done by women with high school education level, essentially technicians or nursing assistants (Tables 1 and 2).

Figure 2 refers to the workforce in the medicine dispensing units of the health services in SUS primary health care: it was mainly composed of technicians or nursing assistants $(\mathrm{n}=631 ; 43.0 \%$; 95\%CI 36.0-50.4; $p<0.001)$, followed by pharmacists $(n=291 ; 33.3 \%$; 95\%CI 26.4-40.9; $p<0.001)$.

The worker's education level and qualification in the medicine delivery/dispensing units varied significantly according to the region. In the North, South, and Northeast regions, workers with high school education level (mostly technicians or nursing assistants) predominated, while the Midwest and Southeast had a higher number of pharmacists $(57.1 \%$, 95\%CI 41.0-71.9; 64.1\%, 95\%CI 45.9-78.9; $\mathrm{p}<0.001$ respectively).

Besides pharmacists, nurses also performed activities in this type of unit ( $\mathrm{n}=108 ; 10.8 \%$; 95\%CI 7.2-15.7). In the Northeast, $21.5 \%$ (95\%CI 12.6-34.0) of the cities had a nurse as a professional who delivered medicines in the primary care health units (Figure 2).

\section{DISCUSSION}

All cities that participated in PNAUM - Services had at least one pharmacist in the municipal health network. They were concentrated in the municipal management activities and had been in the position for more than one year, showing a movement towards the consolidation of this sector in the municipal management structure.

PNAUM - Services data show that the pharmaceutical services workforce in the primary health care was mostly composed of women, aged from 18 to 39 years, with permanent employment bond, having been in the position for more than one year or having weekly work hours above $30 \mathrm{~h}$. The education level, in turn, varied according to the activity: higher education degree in coordination posts and technician or assistant level in the health units. 
The pronounced presence of women in the coordination activities of the municipal pharmaceutical services can be a result of the widening of access to higher education in Pharmacy and of the increase in the number of women in the pharmaceutical market. Women are also the majority among the dispensing units' workers, whose predominant education level was high school (technician or assistant).

There are many explanations to the hegemonic presence of women in the workforce, among which notably is the increase of women in society and university. For some authors, the intensification of women participation in the market is also because they are a cheaper workforce and accept to work in precarious conditions. In this context, the literature highlights the polarization of Brazilian female workers, in which, in one side, there are women with higher education and relatively high salaries considering the female workers group, and, on the other side, there are women with low qualification, low salaries, and lesser social recognition? ${ }^{7}$.

In the health area, besides the aforementioned reasons, the traditional "female jobs," or the ones historically and socially identified as "female-like" explain the major presence of woman as nurses, nutritionists, psychologists, social assistants, and midwives. However, we can already observe the insertion of women in male-dominated areas, such as medicine ${ }^{19}$.

Indeed, the literature points out the expansion of female participation in male university careers, e.g., medicine, dentistry, and veterinary medicine; and the rising insertion of women in the health area market, where they already represents more than $70.0 \%$ of the workforce. In many undergraduate courses in health, including Pharmacy courses, women already occupy more than half of the openings. Among the high school level professionals, the feminization tendency seems stronger, representing $86.9 \%$ of technicians and nursing assistants ${ }^{7,12}$.

Wermelinger et al. ${ }^{19}$ bring up an interesting reflection on the most feminine job in the health area: nursing. In a context in which technicality is well established and even explains the male work valuing, the nursing work is disqualified by being a mostly female job. Its activities increasingly demand the mastering of new technologies, including hard ones, both within care and management. However, the nursing work social representation is associated to more human and less technical aspects of health care, which is mistakenly translated as less valuable work. This reflection is important to the results presented in this study, which clearly show the presence of women with higher education in management positions and of women with technician education in medicine dispensing.

Overall, most of the management and health care workers have permanent employment bond (56.0\% and $57.0 \%$, respectively), i.e., they entered public administration by public tenders. Differing from the national outcome, the North and Northeast regions showed proportional distribution between permanent and commission-based workers in the municipal coordination of pharmaceutical services and predominance of contracted workers in dispensing units ( $53.4 \%$ and $48.5 \%$, respectively).

In this context, it is important to highlight that around $35.0 \%$ of dispensing units' workers are contracted or outsourced, which can indicate a tendency of flexibilization or even precarization of labor relations.

While permanent workers are the majority in the Midwest, Southeast, and South regions, the North and Northeast regions stand out by the predominance of contracted workers. Outsourcing represents $7.6 \%$ of the employment bonds in the Southeast region, probably due to many factors, among which are the limitations imposed by the Fiscal Responsibility Law.

Outsourcing - one of the main flexibilization expressions - is an especial way of privatization that public administration uses to partially transfer the responsibility for the production of some services, by hiring third parties. Although it is an efficient way of ensuring the compliance with the Fiscal Responsibility Law, the advantages and/or disadvantages of flexibilization depend on the point of view, for it is important to point out two tendencies in this process: the job protection deregulation and the precariousness of labor relations, with consequent distinction of job and salary and a tendency to the fragmentation of labor relations ${ }^{3,11}$. 
Although other professional categories can take part in the management, structuring, and organization, pharmacists (90.7\%) perform the municipal coordination of pharmaceutical services in all country's regions, regionally varying from $84.7 \%$ in the Northeast to $95.0 \%$ in the South. This is probably due to many factors: from the existence of sector guiding policies, such as PNAF, to the pharmaceutical services reorientation actions in SUS and the structuring of pharmaceutical services in the cities ${ }^{4}$.

According to the world workforce report on Pharmacy ${ }^{9}$, in countries with low per capita income (e.g. Republic of the Congo and Haiti), the lack of pharmacists resulted in the dependence on high school level workers. In high per capita income countries (e.g. Australia, United Kingdom, and Japan), pharmacists are the majority in the workforce composition. The participation of high school level workers, usually regulated and qualified professionals to assist the pharmacist, varies from $43.2 \%$ in Europe to $28.4 \%$ in Americas, while in the Southeast Asia it represents $67.5 \%$ of the total pharmaceutical area workforce. It is important to highlight that these outcomes refer to the work market in general, without any specific approach to the primary health care services in the analyzed countries.

In Brazil, the scenario seems favorable concerning the number of pharmacists. According to the Brazilian Ministry of Labor and Social Security ${ }^{a}$, there was 5.4 pharmacists per 10,000 inhabitants in 2013, a number higher than in countries such as Mexico, India, and all African countries, but lower than in many European countries and in the United States of America. Considering all those who work under professional registration, in 2014, the Conselho Federal de Farmácia (CFF Federal Pharmacy Council) estimated nine pharmacists for each 10,000 inhabitants ${ }^{17}$.

The discussion on the pharmaceutical services workforce in SUS, however, is unique and deserves observation. Between 2008 and 2013, the number of pharmacists registered in the Unidades Básicas de Saúde (UBS - Basic Health Units) grew 75.0\% in the country. Excluding the Northeast (45.0\%), the growth rates were higher than $50.0 \%$ in the other regions; two factors possibly enabled it: the implementation of the Núcleo de Apoio à Saúde da Família (NASF - Family Health Support Center) and the growth of pharmaceutical services in the country. Besides that, Brazil is one of the few countries who have a public pharmaceutical service model in which pharmacists coordinate all activities related to the medicine chain in government spheres, from selection to use $e^{4,6}$.

The pharmaceutical hegemony identified in the municipal management of pharmaceutical services is not reproduced in dispensing units. The high school level workers, especially technicians and nursing assistants, occupied most of the work positions (43.0\%), while pharmacists represented $33,3 \%$ of the workforce present in these units. When we verified the technical responsibility for dispensing units, we verified that $43.0 \%$ of them had pharmacists in charge (varying from $18.6 \%$ in the Northeast to $72.0 \%$ in the Southeast).

Despite the high growth rates, from $50.0 \%$ to $150.0 \%$ - as in the case of speech and language therapists (55.0\%), pharmacists (75.0\%), physical therapists (78\%), nutritionists (83\%), and physical education professionals $(145.0 \%)$-, these categories still have low percentage participation in the UBS's workforce, varying from $0.1 \%$ to $3.0 \%$. In 2008 , pharmacists represented $2.9 \%$ of all UBS registered workers ${ }^{6}$.

Similar to the pattern in low and high-income countries, we also observed in Brazilian regions the hegemony shifting between pharmacists and high school level workers in dispensing units. The pharmacists' participation varied from $8.1 \%$ in the Northeast to $64.1 \%$ in the Southeast, while technicians and assistants predominated in the North (66.6\%) and represented $19.0 \%$ of the workforce in the Southeast. This is probably due to the same factors identified in the world regions, among which are notably the courses offer (high and technical education), Human Development Index (HDI), among other factors ${ }^{8,9}$.

In fact, the Southeast region concentrates the pharmaceutical education in the country: in 2013, there were 216 Pharmacy courses (50.0\%), 14,475 students, and 7,626 graduated, while the North region had 27 courses, 1,802 students, and only 862 graduated. In addition, 
Southeast and South have the best HDIs. In this sense, it seems that the predominance of higher education professionals (especially pharmacists) depends on the offer of higher education courses and on the conditions of health professionals' fixation, which usually depend on the regional wealth level and development ${ }^{\mathrm{b}, \mathrm{c}}$.

It is also important to consider the type of organization of medicine dispensing units in the different regions. In the Southeast region, there is a higher concentration of centralized pharmacies and the consequent decrease in the number of dispensing units in the UBS. Therefore, the decrease in units with medicine dispensing increases the proportion of units that have pharmacists, even though the absolute number of pharmacists does not show such difference.

Generally, pharmacists have been expanding their functions and responsibilities in primary health care all around the world, clearly focusing on direct patient care. Studies on the pharmaceutical workforce carried out in the United States of America identified that service provision and patient assistance by pharmacists have increased. The sector of medicine supplier pharmacists who also care for patients went from $17.0 \%$ (2009) to $48.0 \%$ (2014). Nevertheless, the medicine suppliers' maintenance in stable levels suggests the need to keep the pharmacists also involved in the medicine offer as an essential activity to the good performance of health services ${ }^{16}$.

In conclusion, the professionalization of municipal management functions in the organization of the pharmaceutical services workforce in the SUS primary health care is an achievement. However, there are significant deficiencies in the workforce composition of medicine dispensing units, which may affect the quality of the medicine use and its results on health. Despite the representative sampling from all the regions and population ranges, study limitations may have created bias, such as in the municipal dispensing units' sampling, since it presents many possibilities of organization and distribution in different ways among each other. The information registered here were gathered from interviews with the professionals responsible for the municipal pharmaceuticals services and with workers who, during data collection, identified themselves as responsible for the medicine dispensing in the units, thus prone to interpretation bias.

\section{REFERENCES}

1. Angonesi D, Sevalho G. Atenção Farmacêutica: fundamentação conceitual e crítica para um modelo brasileiro. Cienc Saude Coletiva. 2010;15 Supl 3:3603-14. https://doi.org/10.1590/S1413-81232010000900035

2. Álvares J, Alves MCGP, Escuder MML, Almeida AM, Izidoro JB, Guerra Junior AA, et al. Pesquisa Nacional sobre Acesso, Utilização e Promoção do Uso Racional de Medicamentos: métodos. Rev Saude Publica. 2017;51 Supl 2:4s. https://doi.org/10.11606/S1518-8787.2017051007027

3. Alves SMP, Coelho MCR, Borges LH, Cruz CAM, Massaroni L, Maciel PMA. A flexibilização das relações de trabalho na saúde: a realidade de um Hospital Universitário Federal. Cienc Saude Coletiva. 2015;20(10):3043-50. https://doi.org/10.1590/1413-812320152010.11592014

${ }^{\mathrm{b}}$ Observa RH - Estação de Trabalho IMS/UERJ. SIGRAS - Sistema de Sistema de Indicadores das Graduações em Saúde. Rio de Janeiro: IMS/ UERJ; 2013 [cited 2017 Jan 26]. Available from: http://www. obsnetims.org.br/sigras c Instituto de Pesquisa Econômica Aplicada. O Índice de Desenvolvimento Humano Municipal Brasileiro 2013. Brasília (DF): PNUD, IPEA, FJP; 2013 [cited 2017 Jan 26]. (Série Atlas de Desenvolvimento Humano no Brasil 2013). Available from: http://www.ipea.gov.br/portal/ images/stories/PDFs/130729_ AtlasPNUD_2013.pdf
4. Araújo ALA, Pereira LRL, Ueta JM, Freitas O. Perfil da assistência farmacêutica na atenção primária do Sistema Único de Saúde. Cienc Saude Coletiva. 2008;13 Supl 6:11-7. https://doi.org/10.1590/S1413-81232008000700010

5. Arrais PSD, Barreto ML, Coelho HLL. Aspectos dos processos de prescrição e dispensação de medicamentos na percepção do paciente: estudo de base populacional em Fortaleza, Ceará, Brasil. Cad Saude Publica. 2007;23(4):927-37. https://doi.org/10.1590/S0102-311X2007000400020

6. Carvalho MN, Dalla Costa EMO, Sakai MH, Gil CRR, Leite SN. Expansão e diversificação da força de trabalho de nível superior nas Unidades Básicas de Saúde no Brasil, 2008 - 2013. Saude Debate. 2016;40(109):154-62. https://doi.org/10.1590/0103-1104201610912

7. Guedes MC. A inserção dos trabalhadores mais escolarizados no mercado de trabalho brasileiro: uma análise de gênero. Trab Educ Saude. 2010;8(1):55-75. https://doi.org/10.1590/S1981-77462010000100004

8. Hawthorne N, Anderson C. The global pharmacy workforce: a systematic review of the literature. Hum Resour Health. 2009;7:48. https://doi.org/10.1186/1478-4491-7-48 
9. International Pharmaceutical Federation. Global Pharmacy: workforce report, 2012. The Hague; 2012 [cited 2017 Jan 26]. Available from: http://www.fip.org/files/members/library/ FIP_workforce_Report_2012.pdf

10. Machado CR, Dal Poz MR. Sistematização do conhecimento sobre as metodologias empregadas para o dimensionamento da força de trabalho em saúde. Saude Debate. 2015;39(104):239-54. https://doi.org/10.1590/0103-110420151040498

11. Marques APP. Reestruturação produtiva e recomposições do trabalho e emprego: um périplo pelas "novas" formas de desigualdade social. Cienc Saude Coletiva. 2013;18(6):1545-54. https://doi.org/10.1590/S1413-81232013000600007

12. Matos IB, Toassi RFC, Oliveira MC. Profissões e ocupações de saúde e o processo de feminização: tendências e implicações. Athenea Digit. 2013 [cited 2017 Jan 26];13(2):239-44. Available from: http://www.lume.ufrgs.br/bitstream/handle/10183/118035/000894801.pdf?sequence=1

13. Paim J, Travassos C, Almeida C, Bahia L, Macinko J. The Brazilian health system: history, advances, and challenges. Lancet. 2011;377(9779):1778-97. https://doi.org/10.1016/S0140-6736(11)60054-8

14. Rizzotto MLF, Gil CRR, Carvalho M, Fonseca ALN, Santos MF. Força de trabalho e gestão do trabalho em saúde: revelações da Avaliação Externa do Programa Nacional de Melhoria do Acesso e da Qualidade da Atenção Básica no Paraná. Saude Debate. 2014;38 No Espec:237-51. https://doi.org/10.5935/0103-1104.2014S018

15. Santos SFS, Benedetti TRB. Cenário de implantação do Núcleo de Apoio à Saúde da Família e a inserção do profissional de Educação Física. Rev Bras Ativ Fis Saude. 2012;17(3):188-94.

16. Schommer JC, Gaither CA, Doucette WR, Kreling DH, Mott DA. Pharmacist contributions to the U.S. Health Care System reported in the 2009 and 2014 National Pharmacist Workforce Surveys. Innov Pharm. 2015 [cited 2017 Jan 26];6(2):1-14. Available from: http://pubs.lib.umn. edu/innovations/vol6/iss2/5

17. Serafin C, Correia Jr D, Vargas M. Perfil do farmacêutico no Brasil: relatório. Brasília (DF): Conselho Federal de Farmácia; 2015 [cited 2017 Jan 26]. Available from: http://www.cff.org.br/ userfiles/file/Perfil\%20do\%20farmac\%C3\%AAutico\%20no\%20Brasil\%20_web.pdf

18. Veber AP, Diehl E, Leite SN, Prospero ENS. Pharmaceutical assistance in local public health services in Santa Catarina (Brazil): characteristics of its organization. Braz J Pharm Sci. 2011;47(1):75-80. https://doi.org/10.1590/S1984-82502011000100009

19. Wermelinger M, Machado MH, Tavares MFL, Oliveira ES, Moysés NMN. A Força de trabalho do setor de saúde no Brasil: focalizando a feminização. Divulg Saude Debate. 2010 [cited 2017 Jan 26];(45):55-71. Available from: http://www.ensp.fiocruz.br/observarh/arquivos/A\%20Forca\%20 de\%20Trabalho\%20do\%20Setor\%20de\%20Saude\%20no\%20Brasil\%20.pdf

Funding: Department for Pharmaceutical Services and Strategic Health Supplies and Department of Science and Technology of the Secretariat of Science, Technology and Strategic Supplies of the Brazilian Ministry of Health (SCTIE/MS - Process 25000,111843/2, Decentralization of FNS Resources).

Authors' Contribution: MNC and SNL analyzed the data wrote the text. SNL, KSC, JA, AAG Jr., FAA, EAC, IAG, OMS, MGOK developed the research project, coordinated data collection, reviewed and approved the text. All authors declare to be responsible for all aspects of the study, ensuring its accuracy and completeness.

Conflict of Interest: KSC declares conflict of interest for being former director of the Brazilian Ministry of Health, the research funding institution. The other authors declare no conflict of interest. 